\title{
Research of the Influence of the Innovations of the Business Models on the Economic Results of the Enterprises
}

Received: 30.08 .2021

Available online: 28.12.2021

\section{Mladen Velev*, Siya Veleva**}

\section{Abstract}

An expanding amount of research and a growing number of scientific publications are devoted to the problems of business model innovations, given their increased theoretical and practical significance. However, this concept is not well developed. There are very few publications in Bulgaria dedicated to the theory of business models and in particular to their innovation. A study of the processes of innovation of business models in Bulgarian enterprises, including their activity and the actual results achieved by their implementation, has not yet been made.

In view of this, the purpose of this article is to briefly present the results of a study of the effects of business model innovation, conducted in a sample of Bulgarian enterprises, as well as to clarify their impact on the economic results of enterprises. The results of the empirical study demonstrate the impact of the innovation capacity of enterprises on the level of economic results achieved through these innovations.
The main hypotheses of the study are:

1. Firms that innovate their business models achieve higher economic results than the average level of results for the respective industries.

2. The positive impact of business model innovations on the economic results of enterprises is stronger than the impact of individual innovations of another kind.

3. The economic results of the conducted innovations of the business models are higher in the industries with high innovation capacity than in the industries with low capacity.

4. The economic results of the conducted innovations of the business models are higher in the big enterprises than in the small and medium enterprises with lower innovation capacity.

The authors hope that this article would provoke a discussion on these and other similar issues related to this topic. The results would assist future research as well as business leaders in making management decisions in developing strategies.

The paper is organized as follows: Section 1 is a introduction and a overview of relevant literature, Section 2 explains the methodology, Section 3 presents the results of the empirical

\footnotetext{
Faculty of Management, Technical University, Sofia, Bulgaria

${ }^{* \star}$ Faculty of Geodesy, University of Architecture Civil Engineering and Geodesy, Bulgaria, Sofia
} 


\section{Articles}

study and a discussion of the results and Section 4 contains the conclusion.

Key words: business models, innovations, innovation capacity, efficiency, research, results.

JEL: 032, 033

\section{Introduction}

Odern market conditions complicate make their competitive positions unstable. Globalization and technical progress complicate market competition. On the one hand, the needs and requirements of consumers are changing rapidly, and changes in science and technology are leading to the rapid obsolescence of existing knowledge, products, equipment and technologies. The number of competing companies is growing - nationally and globally. The scale of production is increasing, and this has its negative impact on the environment. These trends add new requirements to the functioning of enterprises, which are based on the need for continuous and rapid change and improvement. Innovation is becoming a key tool for corporate success. In these conditions, the innovations of the business models of the enterprises become more and more important as a means to achieve high economic results and competitiveness.

Generally speaking, business model innovations aim to overcome some negative trends related to the use of current models and to align the activities of enterprises with current and expected future changes in external conditions. As a result of their implementation, it is expected to improve the economic results of companies and increase their competitiveness. A significant part of company executives are increasingly aware of this importance and invest efforts and
Research of the Influence of the Innovations of the Business Models on the Economic Results of the Enterprises

resources to implement such innovations. In the United States, $40 \%$ of the 27 companies created in the last 25 years that have reached the top 500 in the past 10 years, according to Fortune, have achieved this by innovating their business models (Johnson, Christensen, Kagermann, 2008). Indicative are the results of a survey conducted by the Economist Intelligence Unit among more than 4,000 senior executives of companies around the world. According to them, $54 \%$ of managers would prefer the introduction of a new business model to the introduction of a new product or service as a source of future competitive advantage (Business 2010: Embracing the Challenge of Change, 2005). Similar are the results of a global survey of more than 750 leaders in the private and public spheres conducted by IBM. The authors conclude that competitive pressure increasingly raises the importance of business model innovation higher in the top-priority list of executives than expected (Pohle G., Chapman M, 2006). The same study also found that companies whose revenues grew faster than those of their competitors over the past five years were twice as likely to innovate their business models than their products or processes.

Asswad, Hake and Gomez emphasize that a company's success is not only determined by how good its products are or how innovative its technologies and ideas are. Successful is the company that is able to introduce and use an innovative and different business model (Asswad J., Hake G. and Gomez J., 2016). For its part, Chesbrough argues that today, innovation must embrace business models first and foremost, not just technology and R\&D (Chesbrough, 2007). Amit and Zott add that in the manufacturing sector, many of the innovations and cost-cutting ways that can be implemented have already been implemented. 


\section{Articles}

The big focus should be on the innovation of business models, where the great benefits are hidden. Differentiation by product quality, supply possibilities or production scale is not enough. It is important to innovate in areas where competitors do not operate (Amit R., Zott Ch., 2012). A 2008 study by the Boston Consulting Group shows that companies that focus on innovating their business models are on average $6 \%$ more profitable than those that innovate only on their products or processes (BCG, Business Week / BCG; Innovation Survey, 2008). This is appreciated by a significant number of managers. It shows a new IBM study from 2012, according to which $90 \%$ of the surveyed senior executives plan to innovate their companies' business models over the next three years (IBM Global CEO Study - The Enterprise of the Future, 2012). Giesen argues that for an organization to succeed, it is critical that it should consider and innovate its business model, and that products and services can be copied, and that the business model is a means of differentiation (Giesen et al, 2010 ).

The concept of business model innovation is relatively new and insufficiently well developed. There is no generally accepted definition of this category, nor of the "business model" category itself (Breiby E., Wanberg M., 2011). Most often, the innovation of the business model is defined as reconfiguring the activities from the existing business model of the company so that they are new to the market in which it competes (Santos et al., 2009; Fagerberg, Mowery, Nelson, 2006). This includes changing how a company does business in terms of how it creates, delivers and obtains value (Amit R., Zott Ch., 2012, Teece, 2010, Teece, 2007, Lee J., Shin D., 2010). This innovation redefines the existing product, service and value proposition as well as / or the way the company makes a profit from what it offers to consumers (Bjorkdahl, 2009). Some authors point out that the innovation of the business model can take place by adding new activities, connecting the activities in a new way or changing the participants who perform the individual activities (Amit R., Zott Ch., 2012). According to Geterud and Tegern (Geterud J., Tegern S, 2012), the innovation of the business model is an innovation in one or more of the nine building blocks identified by Osterwalder and Pigneur (Osterwalder and Pigneur, 2010).

The Boston Consulting Group (Lindgardt Z., Reeves M., Stalk G., Deimler M., 2009) distinguishes two main elements of business models: value proposition and operating model. The value proposition answers the question "What do we offer and to whom?" And requires a choice of the following three elements: Target segment (s); Product or service; Return model. The operating model answers the question "How do we deliver the product / service in a profitable way?" And includes: Value chain; Cost model; Organization.

Based on this understanding, the Boston Consulting Group defines that the innovation of the business model is more than the innovation of the product, service or technology. It goes beyond strategies on individual functions, such as focusing on the supply approach or the sales model. Innovation becomes an innovation of the business model when two or more elements of this business model are changed, and the innovation must be both difficult to imitate and to implement (Lindgardt Z., Reeves M., Stalk G., 2009).

A study commissioned by the European Commission (The Need for Innovations in Business Models, 2014) examines business models as consisting of three 


\section{Articles}

main components: Value creation; Business system; Revenue generation. Based on this understanding, the study accepts innovation as an innovation of the business model simultaneously in all three of its main components. This gives radical change. The authors further develop this view, assuming that business model innovation is a complex innovation that includes both the radical elements of the four other major innovations radical product innovation, radical process innovation, radical organizational innovation and radical marketing innovation.

An increasing number of researches and scientific publications are devoted to the problems of business model innovations, given their increased theoretical and practical significance. However, this concept is not well developed. There are very few publications in Bulgaria dedicated to the theory of business models and in particular to their innovation. A study of the processes of innovation of business models in Bulgarian enterprises, including their activity and the actual results achieved by their implementation, has not yet been made.

In view of this, one of the purposes of this publication is to present the results of a study of the effects of innovation on business models, conducted in a sample of Bulgarian enterprises, and to clarify their impact on the economic results of enterprises. The results would guide business leaders in making management decisions to drive innovation and investment. Based on them, various comparisons can be made and analyses relevant to theory and business practice can be performed.
Research of the Influence of the Innovations of the Business Models on the Economic Results of the Enterprises

\section{Methodological bases of the research}

The approach of studying the impact of the business model innovations on the economic results of enterprises is based on the collection, processing and analysis of a significant amount of empirical information from a selected sample of Bulgarian enterprises from different industries. A specially prepared questionnaire for research and statistical methods and specialized software for information processing and analysis were used.

The survey was conducted in 2019 by the method of the survey for a 3-year period. It covers the years 2016, 2017 and 2018, which allows for comparisons. The prepared questionnaire was sent by mail and e-mail, but most of the information was collected in an interview at the workplace. A group of students also took part in the collection of empirical data. Business owners and managers were interviewed. The managers gave direct answers to the questions or assessments on a 7-point scale, with a score of 1 showing the lowest level on the respective indicator, and 7 - the highest level.

The sample includes 150 small, medium and large enterprises from different industries. It is not representative of Bulgarian business, but the results obtained are interesting and indicative of the innovations of business models in enterprises and their results. They can be useful for guiding efforts to improve innovation.

The main hypotheses of the study are:

1. Firms that innovate their business models achieve higher economic results than the average level of results for the respective industries.

2. The positive impact of business model innovations on the economic results of 


\section{Articles}

enterprises is stronger than the impact of individual innovations of another kind.

3. The economic results of the conducted innovations of the business models are higher in the industries with high innovation capacity than in the industries with low capacity.

4. The economic results of the conducted innovations of the business models are higher in the big enterprises than in the small and medium enterprises with lower innovation capacity.

The survey found that not all managers whose opinions had to be surveyed were willing to answer the questions. This necessitated a change in the initially defined representativeness of the individual industries, and the surveyed enterprises to be divided into four aggregate industries, given the affiliation of the managers who responded to the survey. These are - Mining and processing industry, IT sector and telecommunications, Finance and insurance and Others, including enterprises in the field of trade, transport, cultural institutions and others.

For the purposes of the study, the following working definitions were used:

1. Business model - a conceptual tool that shows how the company creates and delivers value to its customers and generates revenue and profit. It contains a network of business participants and characterizes their roles and potential benefits. Its main components are: target market segment / $\mathrm{s}$; value proposition product, service or combinations thereof; key resources; key activities; providers; other business partners - outsourced companies, horizontal integration, financial institutions (banks, insurers), etc .; channels for realization of the production - trade intermediaries; customer relationships; cost structure; revenue structure (Veleva S., Tsvetanova A., Innovation of business models, 2020).

2. Business model innovation - occurs when three or more of the components of the business model change simultaneously.

3. Innovative capacity of the enterprise - its internal ability to identify, develop, absorb and use new knowledge. An adapted methodology developed on the basis of the algorithm for this purpose, published in (Velev M., Atanasova S., 2013), was used for its evaluation.

4. Competitiveness of the enterprise - its ability through continuous renewal and improvement to create and sustainably maintain competitive advantages, leading to high economic results in the long run (Velev M., 2004).

The influence of the innovations of the business models on the economic results is demonstrated with the following indicators, averaged for the whole set of surveyed enterprises (Dimitrov J., 2019):

1. Increase in sales;

2. Increasing the competitiveness of products/ services;

3. Increasing labor productivity in the enterprise;

4. Reduction of unit costs in the enterprise;

5. Improving the financial results of the enterprise.

6. Growth of the enterprise;

7. Improving environmental protection.

8. Increasing the competitiveness of enterprises.

For the purposes of the analysis, comparisons were made of the average levels of the indicated indicators for:

- The total number of surveyed companies from the respective population; 


\section{Articles}

- The part of the companies from this set, which have made innovations;

- Some of the companies in this group that have innovated their business models.

The comparisons were made in the following main directions:

- By years of the studied period;

- Total for the companies in the sample;

- By size of companies;

- By industry

The performed comparisons between the average indicators for the respective set of analyzed companies give an idea of the importance of innovating the business models. The observed differences in the levels of the
Research of the Influence of the Innovations of the Business Models on the Economic Results of the Enterprises

indicators also provide an answer to the set research hypotheses.

\section{Main results of the research.}

The limited scope of the present study does not allow a detailed presentation of the results of the study. For this reason, only the summarized results for the whole set of surveyed enterprises are presented here.

Of the surveyed sample of 150 companies, 90 are located in Sofia, 40 - in large cities and 20 in small towns. Of the surveyed enterprises, 10 are large enterprises and 140 are small and medium. The study is for a period of three years.

The distribution of companies by industry is shown in Table 1.

Table 1. The distribution of the surveyed companies by industries

\begin{tabular}{|l|c|c|c|c|c|c|}
\hline \multirow{2}{*}{ Industries } & \multirow{2}{*}{ Total } & & \multicolumn{4}{c|}{ Including } \\
\cline { 5 - 8 } & & & $\begin{array}{c}\text { Big } \\
\text { enterprises }\end{array}$ & $\%$ & $\begin{array}{c}\text { Small and medium } \\
\text { enterprises }\end{array}$ & \% \\
\hline 1. Mining and processing industry & & & 2 & 2 & 98 & 98 \\
\hline 2.IT sector and telecommunications & 13 & 8.67 & 1 & 7.69 & 12 & 92.31 \\
\hline 3. Finance and insurance & 11 & 7.33 & 5 & 45.45 & 6 & 54.55 \\
\hline $\begin{array}{l}\text { 4. Others - trade, transport, cultural } \\
\text { institutions, etc.. }\end{array}$ & 26 & 17.33 & 2 & 7.69 & 24 & 92.31 \\
\hline Total: & $\mathbf{1 5 0}$ & $\mathbf{1 0 0}$ & $\mathbf{1 0}$ & $\mathbf{6 . 6 7}$ & $\mathbf{1 4 0}$ & $\mathbf{9 3 . 3 3}$ \\
\hline
\end{tabular}

The average results for the level of | adapted for the purpose methodology are innovation capacity of the enterprises from the separate branches, determined using the presented in Table 2.

Table 2. Weighted average estimates of innovation capacity of the surveyed enterprises by industries

\begin{tabular}{|l|c|c|}
\hline \multicolumn{1}{|c|}{ Industries } & $\begin{array}{c}\text { Average innovation capacity of } \\
\text { all enterprises }\end{array}$ & $\begin{array}{c}\text { Average innovation capacity of enterprises } \\
\text { that have made innovations }\end{array}$ \\
\hline 1. Mining and processing industry & 211.576 & 231,00 \\
\hline 2. IT sector and telecommunications & 363.66 & 281.62 \\
\hline 3. Finance and insurance & 357.48 & 372,73 \\
\hline $\begin{array}{l}\text { 4. Others - trade, transport, cultural } \\
\text { institutions, etc.. }\end{array}$ & 189.14 & 204,46 \\
\hline Average for the whole sample: & $\mathbf{2 3 1 . 5 6 7 6}$ & $\mathbf{2 7 0 , 8 2}$ \\
\hline
\end{tabular}




\section{Articles}

The values of the calculated indicators for the innovation capacity of the enterprises are in the range from 13 to 637 . The higher they are, the higher the innovation capacities of the respective enterprises. The results shown in the table show that the average innovation capacity of the enterprises in the whole sample is relatively low, it is at a level lower than half of the maximum possible. This indicator is the lowest in enterprises in the sectors "Other" and "Mining and processing" and relatively higher (slightly above average) in the sectors "IT sector and telecommunications" and „Finance and insurance“. The calculated average innovation capacity of the enterprises from the separate branches, which have carried out innovations, is significantly higher than the average capacity of all enterprises from the respective branches.

The results obtained showed that the weighted average estimates of the innovation capacity of large and small and mediumsized enterprises, determined for the sample studied, differ significantly. The innovation capacity of large enterprises is 342.75 , while that of small and medium-sized enterprises only 223,626. By individual industries, these results are shown in Table 3.

Table 3. Weighted average estimates of innovation capacity of large and small and medium enterprises by industry

\begin{tabular}{|l|c|c|c|}
\hline \multicolumn{1}{|c|}{ Industries } & Total & Big enterprises & $\begin{array}{c}\text { Small and medium } \\
\text { enterprises }\end{array}$ \\
\hline 1. Mining and processing industry & $\mathbf{2 1 1 . 5 7 6}$ & 266.75 & 210.45 \\
\hline 2.IT sector and telecommunications & $\mathbf{3 6 3 . 6 6}$ & 401 & 360.55 \\
\hline 3. Finance and insurance & $\mathbf{3 5 7 . 4 8}$ & 397.6 & 324.05 \\
\hline $\begin{array}{l}\text { 4. Others - trade, transport, cultural } \\
\text { institutions, etc.. }\end{array}$ & $\mathbf{1 8 9 . 1 4}$ & 252.5 & 183.86 \\
\hline Total: & $\mathbf{2 3 1 . 5 6 7 6}$ & $\mathbf{3 4 2 . 7 5}$ & $\mathbf{2 2 3 . 6 2 6}$ \\
\hline
\end{tabular}

It is evident that the indicator is significantly lower for small and medium enterprises in all surveyed industries. This shows that, in general, these enterprises are still not well developed and are highly vulnerable to abrupt changes in markets and the business environment. In the case of large enterprises, innovation capacity is higher than the average for the sectors concerned, although it is slightly higher than the average for the scale only in the IT sector and telecommunications and finance and insurance.

It was found that for the whole period 176 enterprises have made innovations, and 33 of them have innovated their business models. This shows relatively good innovation activity. It should be borne in mind here that some companies have not made innovations, while others have made one or more changes over the years of the period. This is largely due to the higher innovation capacity of these enterprises. The total number of innovations carried out by the whole sample of enterprises is 271 , and the number of innovations per 1 enterprise is 1.81 on average. The total number of innovations in business models is 33, an average of 0.22 per 1 enterprise.

It was found that the different surveyed industries have different innovation activity to update their business models (Table 4) and this activity increases with the increase of the average level of innovation capacity of the industry. 
Table 4. Level of innovation capacity and number of innovations of the business models of 1 enterprise by industries (for the whole studied period)

\begin{tabular}{|l|c|c|c|}
\hline \multicolumn{1}{|c|}{ Industries } & $\begin{array}{c}\text { Innovation } \\
\text { capacity level }\end{array}$ & $\begin{array}{c}\text { Number of } \\
\text { business model } \\
\text { innovations in total }\end{array}$ & $\begin{array}{c}\text { Number of innovations } \\
\text { in the business models } \\
\text { per 1 enterprise }\end{array}$ \\
\hline 1. Mining and processing industry & 211.576 & 12 & 0,12 \\
\hline 2.IT sector and telecommunications & 363.66 & 13 & 1,00 \\
\hline 3. Finance and insurance & 357.48 & 8 & 0,73 \\
\hline 4. Others - trade, transport, cultural institutions, etc.. & 189.14 & 0 & 0,00 \\
\hline Total: & $\mathbf{2 3 . 5 6 7 6}$ & $\mathbf{3 3}$ & $\mathbf{0 , 2 2}$ \\
\hline
\end{tabular}

It can be assumed with a high degree of probability that the higher innovation capacity of the IT and Telecommunications and Finance and Insurance sectors is the basis of their higher innovation activity.

This finding of the relationship between the level of innovation capacity and the number of innovations in business models was confirmed by the results for enterprises of different sizes. As the level of their innovation capacity increases, so does their innovation activity. These results are shown in Table 5.

Table 5. Level of the innovation capacity and number of innovations of the business models per 1 enterprise by branches and size (for the whole studied period)

\begin{tabular}{|c|c|c|c|c|c|c|}
\hline Industries & $\begin{array}{l}\text { Level of } \\
\text { innovation } \\
\text { capacity of big } \\
\text { enterprises }\end{array}$ & $\begin{array}{l}\text { Number of } \\
\text { innovations in } \\
\text { the business } \\
\text { models of big } \\
\text { enterprises }\end{array}$ & $\begin{array}{c}\text { Number of } \\
\text { innovations per } 1 \\
\text { big enterprise }\end{array}$ & $\begin{array}{l}\text { Level of } \\
\text { innovation } \\
\text { capacity of small } \\
\text { and medium } \\
\text { enterprises }\end{array}$ & $\begin{array}{l}\text { Number of } \\
\text { innovations in } \\
\text { the business } \\
\text { models of small } \\
\text { and medium } \\
\text { enterprises }\end{array}$ & $\begin{array}{l}\text { Number of } \\
\text { innovations } \\
\text { per } 1 \text { small } \\
\text { and medium } \\
\text { enterprise }\end{array}$ \\
\hline $\begin{array}{l}\text { 1. Mining and processing } \\
\text { industry }\end{array}$ & 266.75 & 3 & 0,3 & 210.45 & 9 & 0.064 \\
\hline $\begin{array}{l}\text { 2.IT sector and } \\
\text { telecommunications }\end{array}$ & 401 & 3 & 0,3 & 360.55 & 10 & 0.071 \\
\hline 3. Finance and insurance & 397.6 & 7 & 0,7 & 324.05 & 1 & 0.007 \\
\hline $\begin{array}{l}\text { 4. Others - trade, } \\
\text { transport, cultural } \\
\text { institutions, etc.. }\end{array}$ & 252.5 & 0 & 0 & 183.86 & 0 & 0 \\
\hline TOTAL: & 342.75 & 13 & 1,3 & 223.26 & 20 & 0.143 \\
\hline
\end{tabular}

The assessment of the impact of innovation capacity on the economic results of enterprises is based on the understanding that it favors the implementation of innovations with a high level of innovation, as a result of which the overall results of enterprises are improved. To determine this impact, managers' assessments of the dynamics of the performance indicators of their enterprises were taken into account. The estimates are for the change achieved at the end of the study period compared to its initial year in the range from 1 - no improvement was achieved, to 7 a very large improvement was achieved. The summarized results are shown in the following table: 


\section{Articles}

Table 6. Average growth rates of business results for the period under study in enterprises that made innovations

\begin{tabular}{|c|c|c|c|c|}
\hline № & $\begin{array}{c}\text { Results } \\
\text { (increase in\%) }\end{array}$ & $\begin{array}{c}\text { Average of the sampled } \\
\text { enterprises }\end{array}$ & $\begin{array}{l}\text { On average for } \\
\text { enterprises that have } \\
\text { made an innovation }\end{array}$ & $\begin{array}{c}\text { On average for } \\
\text { companies that have } \\
\text { innovated the business } \\
\text { model }\end{array}$ \\
\hline 1. & Increase in sales; & 3,45 & 4,09 & 4,72 \\
\hline 2. & Increasing the competitiveness of products / services; & 3,10 & 3,71 & 4,55 \\
\hline 3. & Increasing labor productivity in the enterprise; & 4,12 & 5,07 & 6,01 \\
\hline 4. & Reduction of unit costs in the enterprise; & 3.03 & 3,87 & 4,95 \\
\hline 5. & Improving the financial results of the enterprise. & 3,34 & 4,22 & 5,56 \\
\hline 6. & Growth of the enterprise; & 3,19 & 3,87 & 4,65 \\
\hline 7. & Improving environmental protection. & 2,11 & 2,46 & 2,85 \\
\hline 8. & Increasing the competitiveness of enterprises. & 2,44 & 3,20 & 4,11 \\
\hline
\end{tabular}

The comparison of the achieved results of the enterprises, which carried out some innovation, with those of the sampled enterprises as a whole, show that the enterprises, which carried out innovation, achieved a greater improvement of their economic results, according to all studied indicators. For their part, the companies that have innovated their business model have achieved significantly better results than both groups of companies with which it is compared. It can be concluded that this is due to their increased and properly targeted innovation activity, which is a result of higher levels of their innovation capacity.

This conclusion is also confirmed by the results for the growth of the business results for the studied period in the enterprises, which have innovated their business models in the separate branches (Table 7).

Table 7. Average growth rates of business results for the period under review of enterprises that have implemented innovations in their business models, by industry (brackets indicate the average increase in business results of enterprises that have made some kind of innovation)

\begin{tabular}{|c|c|c|c|c|c|}
\hline № & $\begin{array}{c}\text { Results } \\
\text { (increase in\%) }\end{array}$ & $\begin{array}{c}\text { Mining and } \\
\text { processing industry }\end{array}$ & $\begin{array}{l}\text { IT sector and } \\
\text { telecommunications }\end{array}$ & $\begin{array}{l}\text { Finance and } \\
\text { insurance }\end{array}$ & $\begin{array}{l}\text { Others - trade, } \\
\text { transport, cultural } \\
\text { institutions, etc. }\end{array}$ \\
\hline 1. & Increase in sales; & $4,15 / 3,83 /$ & $5,19 / 4,92 /$ & $4,95 / 4,59 /$ & $/ 3,51 /$ \\
\hline 2. & $\begin{array}{l}\text { Increasing the competitiveness of } \\
\text { products / services; }\end{array}$ & $4,3 / 3,7 /$ & $4,89 / 3,95 /$ & $4,35 / 3,8 /$ & $/ 3,2 /$ \\
\hline 3. & $\begin{array}{l}\text { Increasing labor productivity in the } \\
\text { enterprise; }\end{array}$ & $5,37 / 4,73 /$ & $6,58 / 6,43 /$ & $5,68 / 5,20 /$ & $/ 4,33 /$ \\
\hline 4. & $\begin{array}{l}\text { Reduction of unit costs in the } \\
\text { enterprise; }\end{array}$ & $5,45 / 4,03 /$ & $4,98 / 4,57 /$ & $4,0 / 3,50 /$ & $/ 2,00 /$ \\
\hline 5. & $\begin{array}{l}\text { Improving the financial results of the } \\
\text { enterprise. }\end{array}$ & $5,05 / 4,07 /$ & $5,82 / 4,97 /$ & $5,78 / 4,77 /$ & $/ 2,93 /$ \\
\hline 6. & Growth of the enterprise; & $4,07 / 3,6 /$ & $5,08 / 4,85 /$ & $4,83 / 4,37 /$ & $/ 3,07 /$ \\
\hline 7. & Improving environmental protection. & $3,23 / 2,6 /$ & $2,46 / 2,23 /$ & $2,9 / 2,47 /$ & $/ 1,73 /$ \\
\hline 8. & $\begin{array}{l}\text { Increasing the competitiveness of } \\
\text { enterprises. }\end{array}$ & $3,73 / 3,02 /$ & $4,48 / 3,87 /$ & $4,08 / 3,70 /$ & $/ 2,53 /$ \\
\hline
\end{tabular}




\section{Articles}

It is evident that the average growth rates of the business results for the studied period in the enterprises of the separate branches, which have innovated their business models, significantly exceed the average growth rates for all enterprises, which have made innovations of some kind. This shows that business model innovations are much more effective than individual innovations of another kind. They also have a stronger impact on increasing the competitiveness of enterprises. The highest economic results from the innovation of business models were achieved by the industries with the highest average levels of innovation capacity, namely "IT sector and telecommunications" and „Finance and insurance". A small exception is
Research of the Influence of the Innovations of the Business Models on the Economic Results of the Enterprises

observed in the indicators "Reduction of unit costs in the enterprise" and "Improvement of environmental protection" for the sector "Mining and processing industry". This can be explained primarily by the inherent resource absorption and lower environmental friendliness of this industry.

The conclusion that the achieved economic results from the conducted innovations of the business models exceed those of the other enterprises, as well as that they are directly dependent on the level of the innovation capacity of the enterprises, is confirmed by tracking the results and by enterprises of different size. different average capacity). Moreover, this is found in all studied industries.

\section{Table 8. Average growth rates of business results for the period under study in enterprises of different sizes that have innovated their business models (brackets indicate the average increase in business results of enterprises that have made some kind of innovation)}

\begin{tabular}{|l|l|l|l|l|}
\hline № & Results (increase in\%) & $\begin{array}{l}\text { Average for big } \\
\text { enterprises }\end{array}$ & $\begin{array}{l}\text { Average for small and } \\
\text { medium enterprises }\end{array}$ & $\begin{array}{l}\text { Excess in big enterprises } \\
\text { compared to small and } \\
\text { medium (\%) }\end{array}$ \\
\hline 1. & Increase in sales; & $4,92 / 4,37 /$ & $4,65 / 4,03 /$ & $5,57 / 8,44 /$ \\
\hline 2. & Increasing the competitiveness of products / services; & $4,87 / 3,90 /$ & $4,34 / 3,68 /$ & $10,97 / 5,98 /$ \\
\hline 3. & Increasing labor productivity in the enterprise; & $6,22 / 5,53 /$ & $5,72 / 4,98 /$ & $7,90 / 11,04 /$ \\
\hline 4. & Reduction of unit costs in the enterprise; & $5,51 / 4,86 /$ & $4,58 / 4,08 /$ & $16,81 / 19,12 /$ \\
\hline 5. & Improving the financial results of the enterprise. & $6,27 / 4,97 /$ & $5,48 / 4,08 /$ & $12,60 / 21,81 /$ \\
\hline 6. & Growth of the enterprise; & $5,44 / 4,80 /$ & $4,39 / 3,71 /$ & $19,21 / 29,38 /$ \\
\hline 7. & Improving environmental protection. & $3,45 / 3,23 /$ & $2,45 / 2,32 /$ & $28,86 / 39,22 /$ \\
\hline 8. & Increasing the competitiveness of enterprises. & $4,93 / 4,37 /$ & $3,57 / 2,95 /$ & $27,58 / 48,14 /$ \\
\hline \multicolumn{2}{|l|}{ Ratings from 1 - no improvement has been achieved, to 7 - a very big improvement has been achieved. } & Average $16,19 / 22,89 / \%$ \\
\hline
\end{tabular}

These data clearly show that companies in both groups that have innovated their business models have achieved a significantly higher increase in their positive economic results than companies that have made some kind of innovation, and all the studied indicators. The comparison of the results achieved by big enterprises with those of small and medium enterprises shows that large enterprises that have implemented some innovation have achieved a greater improvement in their economic results (on average by $22.89 \%$ ). For companies that have innovated their business models, this excess is $16.19 \%$, which again proves their higher efficiency and confirms its dependence on the level of innovation capacity. These innovations have had a beneficial effect on 


\section{Articles}

the economic performance of both groups of companies. In analyzing this excess, it should be borne in mind that small and medium-sized enterprises that have innovated their business models also had an above-average innovation capacity for this group.

The performed correlation analysis showed that the level of innovation capacity had a moderately positive impact on the economic results of the conducted innovations of the business models. This is true both for the whole sample of surveyed companies and for companies from different industries.

\section{Conclusion}

The main purpose of this presentation was to present the results of an empirical study of the effects of innovation on business models, conducted in a sample of Bulgarian companies, as well as to clarify their impact on the business results of companies. These results demonstrate the impact of the innovation capacity of enterprises on the level of economic results achieved through these innovations.

The studied sample of enterprises is not representative of the Bulgarian economy, but the results are interesting and indicative of the effectiveness of the innovations of business models and their impact on individual business results and competitiveness of enterprises. These results, as well as the conclusions made on the basis of their analysis, reflect the investment and innovation activities of enterprises over time. They can be discussed and some of them can be disputed. However, they show the collective experience of a relatively large group of companies so far and can be a guide for their future work related to the implementation of innovations and innovation management.
These results indicate a positive relationship between the innovation capacity of enterprises and their activity to innovate business models. The higher level of capacity has led to greater innovation activity and this is found both for the different industries studied and for different sized enterprises. Big enterprises from all industries have a higher innovation capacity than small and mediumsized ones, as well as a higher activity for innovation of their business models.

The results show that the implemented innovations of business models have had a positive impact on all of the studied indicators for assessing business results, although to varying degrees. The enterprises that have innovated their business models have achieved higher economic results not only in comparison with the average level of results for the respective branches, but also in comparison with the enterprises that have made some other kind of innovations. This confirms the correctness of the first and second research hypotheses.

It was found that the economic results of the conducted innovations of the business models are higher in the industries with high innovation capacity than in the industries with low capacity. The economic performance of big enterprises was also significantly higher than that of small and medium-sized enterprises. This is evident not only from the observed difference of the indicators, but also from the visible tendency for their improvement during the studied period. Apparently, their higher innovation capacity has favored, on the one hand, the implementation of a relatively larger number of innovations of business models and, on the other hand, the achievement of their higher level of novelty and significance. However, it should be borne in mind that the improvement of some of these results 


\section{Articles}

is due to the improving economic situation in the country during the period. In addition, the improvements are the result not only of innovation efforts within individual years, but also of those of previous years. The results of previous years were a consequence of the then level of innovation capacity, but they themselves have contributed to improving its condition. This proves the third and fourth research hypotheses.

\section{References}

Amit R., Zott Ch., Creating Value Through Business Model Innovation, MIT Sloan Management Review, Spring 2012, Vol.53, No3.

Asswad J., Hake G. and Gomez J., The Obstacles of Sustainable business Model Innovations, Association for Information Systems, CONF-IR, 2016.

BCG, Business Week/BCG Innovation Survey, 2008.

Bessant, T.J. and Pavitt, K., 2005, Managing Innovation. Wiley. 3rd edition;

Björkdahl, J. (2009) 'Technology crossfertilization and the business model: the case of integrating ICTs in mechanical engineering products', Research Policy, Vol. 38 No. 9, pp.1468-1477.

Breiby E., Wanberg M., Successful Business Model Innovation, NTNU - Trondheim, Norvewegian University of Science and Technology, 2011.

Business 2010: Embracing the Challenge of Change", white paper, Economist Intelligence Unit, New York, February 2005.

Chesbrough $\mathrm{H}$., Business model innovation: it's not just about technology anymore, Strategy\&Leadership, vol.35 No 6, 2007, Emerald Group Publishing Limited, ISSN 1087-8572.
Research of the Influence of the Innovations of the Business Models on the Economic Results of the Enterprises

Cohen, W., and Levinthal, D., 1990, Absorptive Capacity: A new perspective on learning and innovation, Administrative Science Quarterly, Vol. 35;

Cohen, W., and Levinthal, D., 1994, Fortune Favors the Prepared Firm, Management Science;

Dimitrov J., Economic adaptability of the industrial enterprise, „TU - Sofia“, S.2019, ISBN: 978-619-167-387-2;

Geterud J., Tegern S., Business Model Innovation. An empirically derived framework for early stage business model innovation, Chalmers University of Technology, Sweden, 2012.

Giesen, E. et al., 2010. When and how to innovate your business model. Strategy \& Leadership, 38(4), pp.17-26.

IBM Global CEO Study - The Enterprise of the Future, 2012.

Johnson, M.W., Christensen, C.C., and Kagermann, H., 2008, Reinventing your business model, Harvard Business Review, pp 50-59

Fagerberg, J., Mowery, D.C. \& Nelson, R.R., 2006. The Oxford Handbook of Innovation, Oxford University Press.

Lee J., Shin D., Hong Y., Kim Y., Business Model Design Methodology for Innovative Product-Service Systems: a strategic and structured approach, International conference on engineering design, ICED 11, 15-18 August 2011, Technical University of Denmark.

Lindgardt Z., Reeves M., Stalk G., Deimler M., Business Model Innovation - When the game gets tough, change the game, The Boston Consulting Group, December 2009.

Lane P., Koka, B. and Pathak, S., 2006, The Reification of Absorptive Capacity: A Critical Review and Rejuvenation of the Construct, Academy of Management Review, 2006, Vol. 31, No 4; 


\section{Articles}

Neely A., Hii J., The Innovative Capacity of Firms, Nang Yan Business Journal, 1.1.2012;

Osterwalder, A. \& Pigneur, Y., 2010. Business Model Generation: A Handbook for Visionaries, Game Changers, and Challengers T. Clark, ed., Wiley.

Pohle G., Chapman M., IBM's Global CEO Report 2006: Business Model Innovation Matters", Strategy and Leadership 34, No5 (2006).

Santos, J. et al. (2009) «Toward a Theory of Business Model Innovation within Incumbent Firms», Working Paper version 20.03.2009. Fontainebleue: INSEAD.

Takov B., 2016, Improving the environmental friendliness and economic results of the industrial enterprise through green process innovations, Technical University of Sofia.

Teece, D.J., 2007. Explicating dynamic capabilities: the nature and microfoundations of (sustainable) enterprise performance. Strategic Management Journal, 28(13), pp.1319- 1350.

Teece, D.J., 2009. Dynamic Capabilities and Strategic Management: Organizing for Innovation and Growth. Oxford University Press, Oxford, New York.

The Need for Innovations in Business Models, School of Business, University of Applied Sciences and Arts, Northwestern Switzerland, European Commission, 2014.

Velev M., Atanasova S., 2013, The technology transfer in Industrial firm, Softrejd, Sofia;

Velev M., 2004, Assessment and analysis of company competitiveness, Softrejd, Sofia;

Veleva S., Tsvetanova A., 2020, Business Model Innovation, Avangard Prima Publishing House, Sofia 